\title{
The use of ensiled olive cake in the diets of Friesian cows increases beneficial fatty acids in milk and Halloumi cheese and alters the expression of SREBF1 in adipose tissue
}

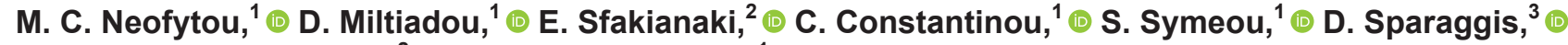 \\ A. L. Hager-Theodorides, ${ }^{2}$ (D) and O. Tzamaloukas ${ }^{1 *}$ (D) \\ ${ }^{1}$ Department of Agricultural Sciences, Biotechnology and Food Science, Cyprus University of Technology, Limassol, PO Box 50329 , Cyprus 3036 \\ ${ }^{2}$ Department of Animal Science, Agricultural University of Athens, 11855 Athens, Greece \\ ${ }^{3}$ Agricultural Research Institute, Nicosia, PO Box 22016, Cyprus 1516
}

\begin{abstract}
This study aimed to evaluate the effect of dietary inclusion of ensiled olive cake, a by-product of olive oil production, on milk yield and composition and on fatty acid (FA) profile of milk and Halloumi cheese from cows. Furthermore, the effect of olive cake on the expression of selected genes involved in mammary and adipose lipid metabolism was assessed in a subset of animals. A total of 24 dairy cows in mid lactation were allocated into 2 isonitrogenous and isoenergetic feeding treatments, named the control $(\mathrm{CON})$ diet and the olive cake (OC) diet, in which part of the forages (alfalfa, barley hay, and barley straw) were replaced with ensiled OC as $10 \%$ of dry matter according to a $2 \times 2$ crossover design with two 28 -d experimental periods. At the end of the second experimental period, mammary and perirenal adipose tissue samples were collected from 3 animals per group for gene expression analysis by quantitative reverse-transcription PCR. The expression of 11 genes, involved in FA synthesis (ACACA, FASN, G6PDH), FA uptake or translocation (VLDLR, LPL, SLC2A1, CD36, FABP3), FA saturation $(S C D 1)$, and transcriptional regulation (SREBF1, $P P A R G$ ), was evaluated. No significant differences were observed between groups concerning milk yield, fat percentage, protein percentage, and protein yield $(\mathrm{kg} / \mathrm{d})$, whereas milk fat yield $(\mathrm{kg} / \mathrm{d})$ increased in the OC group. Dietary supplementation with ensiled OC modified the FA profile of milk and Halloumi cheese produced. There was a significant decrease in the concentration of de novo synthesized FA, saturated FA, and the atherogenic index, whereas long-chain and monounsaturated FA concentration was increased in both milk
\end{abstract}

Received January 21, 2020.

Accepted May 7, 2020.

*Corresponding author: ouranios.tzamaloukas@cut.ac.cy and cheese. Among individual saturated FA, only stearic acid was elevated, whereas among individual monounsaturated FA, increments of oleic acid (C18:1 cis-9) and the sum of C18:1 trans-10 and trans-11 acids were demonstrated in milk and Halloumi cheese produced. Although no diet effect was reported on total polyunsaturated FA, the concentration of CLA cis-9,trans-11 was increased in both milk and Halloumi cheese fat of the OC group. The expression of the genes tested was unaffected apart from an observed upregulation of $S R E B F 1 \mathrm{mRNA}$ expression in perirenal fat from cows fed the OC diet. Milk FA differences observed were not associated with alterations in mammary expression of genes involved in FA synthesis, uptake, translocation, and regulation of lipogenesis. Overall, the inclusion of ensiled OC in cow diets for a 4-wk period improved, beneficially for human health, the lipid profile of bovine milk and Halloumi cheese produced without adversely affecting milk yield and composition or the expression of genes involved in lipid metabolism of mammary and adipose tissues in cows.

Key words: ensiled olive cake, milk fatty acid, Halloumi cheese, gene expression

\section{INTRODUCTION}

Milk fatty acid (FA) composition has been associated with human health and disease prevention (reviewed in Parodi, 2004; Palmquist, 2009; Ferlay et al., 2017). Inclusion of different UFA in the diet of lactating cows is a reasonable attempt to improve milk fat composition for human consumption (reviewed in Chilliard et al., 2000, 2003; Ferlay et al., 2017). Among all the different sources of unsaturated fats that have been used, the use of agroindustrial by-products could be a cost-effective way of enhancing the quality of milk and its products. Crude olive cake (OC), a by-product of olive oil production that is available in appreciable quantities in the Mediterranean basin, represents an interesting 
supplement for ruminants as a forage replacement that may improve the lipids of milk (Molina-Alcaide and Yáñez-Ruiz, 2008).

Supplementation with OC has been mainly used in sheep diets (reviewed in Molina-Alcaide and YáñezRuiz, 2008). Feeding trials including dried (Abbeddou et al. 2011a,b, 2015), partly destoned dried (Vargas-BelloPérez et al., 2013), or partly destoned fresh (Chiofalo et al., 2004) OC showed decreased SFA and increased MUFA, whereas varying results were obtained for CLA or other linoleic acids in dairy ewe milk (Symeou et al., 2019). A limited number of studies have examined the effect of processed OC on the FA composition of milk or cheese produced in goats (Molina-Alcaide et al., 2010; Arco-Pérez et al., 2017) and cattle (Castellani et al., 2017). Castellani et al. (2017) showed an increase in MUFA and a decrease in SFA and in atherogenic and thrombogenic indices in the milk and cheese of cows fed dried olive pomace.

During the last decade, experiments examining the effect of ruminant diets on FA composition also sought to understand the effects of dietary treatments on adipose tissue and mammary gland lipid metabolism and their contribution to changes in milk FA by looking more specifically at the relationship between milk FA composition and expression of lipogenic genes (Bernard et al., 2017; Toral et al., 2017; Fougère and Bernard, 2019). Among the complex network of genes coordinating milk fat synthesis and secretion, acetylCoA-carboxylase $(A C A C A), \mathrm{FA}$ synthase $(F A S N)$, and glucose 6 phosphate dehydrogenase $(G 6 P D H)$ are key genes encoding enzymes involved in de novo FA synthesis, and very low density lipoprotein receptor $(V L D L R)$ in concert with lipoprotein lipase $(L P L)$ take up and hydrolyze triacylglycerides (Bionaz and Loor, 2008). Translocators including solute carrier family 2 member 1 (SLC2A1) and FA translocator $(F A T / C D 36)$ play a major role in FA transport, and FA binding protein 3 (FABP3) provides substrates to stearoyl-CoA-desaturase 1 (SCD1), the most abundant gene in the mammary gland, decreasing the saturation content of FA in ruminant milk (Bionaz and Loor, 2008). Additionally, sterol regulatory element binding transcriptional factor 1 (SREBF1) and peroxisome proliferator activated receptor gamma (PPARG) constitute regulators of milk lipid metabolism (Osorio et al., 2016).

The inclusion of $\mathrm{OC}$ in ruminant feed is quite limited because of its low nutritive value, seasonal availability, and spoilage when stored without preservation for a long time (Hadjipanayiotou, 1999; Owaimer et al., 2004). Despite these disadvantages, OC is characterized by a high oil percentage and high concentration of oleic acid that could improve the milk lipid profile (Chiofalo et al., 2002). Research studies in Cyprus have proposed an ensiling method as an attempt to overcome the limitations of using fresh or dried OC, allowing the use of this by-product in animal nutrition throughout the year (Hadjipanayiotou, 1999). Recently, we examined the effect of the supplementation of Chios sheep diets with ensiled OC on the FA profile of their products (Symeou et al., 2019). So far, no studies have examined the effect of ensiled OC supplementation on the FA content of bovine milk and Halloumi cheese or the possible effect of any form of OC supplementation on bovine lipogenic gene expression. The objective of the present study was to assess the effects of the addition of ensiled crude OC in the diet of mid-lactation Holstein-Friesian cows on (1) the FA composition of milk and Halloumi cheese and (2) the expression of 11 genes involved in FA synthesis (ACACA, FASN, G6PDH), FA uptake or translocation (VLDLR, LPL, SLC2A1, CD36, FABP3), FA saturation ( $S C D 1)$, and transcriptional regulation (SREBF1, PPARG) of lipid metabolism in the mammary and adipose tissues.

\section{MATERIALS AND METHODS}

\section{Animals, Management, and Experimental Diets}

The experiment was performed in the Agricultural Research Institute (facilities in Athalassa, Nicosia) in Cyprus. All experimental procedures were carried out according to the regulations of the national legislation (Republic of Cyprus, 1994) and international guidelines (European Union, 2010) and approved by the corresponding departmental committee of the Cyprus University of Technology. No animals were killed as the experiment was adjusted to the scheduled program of slaughtering for renewing the herd of the Agricultural Research Institute farm.

A total of 24 Holstein-Friesian mid-lactating cows in their fourth lactation were divided into 6 groups of 4 animals each, homogeneous for age, milk yield (mean \pm SEM: $29.31 \pm 1.31 \mathrm{~kg} /$ head per day), and BW (mean \pm SEM: $582.0 \pm 11 \mathrm{~kg}$ ), and allocated randomly to 2 feeding treatments (3 groups per treatment). Animals were used in a replicated $2 \times 2$ Latin square to test the effects of the 2 treatments during two 28-d experimental periods. Cows were housed indoors and assigned to 2 isoenergetic and isonitrogenous feeding regimens (Table 1). The control group (CON) was fed a conventional diet, whereas the OC group received the conventional diet in which part of the forages were replaced with $5 \mathrm{~kg} /$ cow per day of ensiled OC (fresh OC with DM content of $47.7 \%$ ), obtaining a concentrate:forage ratio of 64:36 in both treatments.

The OC was constituted from a mixture of skins, pulp, woody endocarp, and seeds obtained after extrac- 
tion of olive oil from locally cultivated olives (Ladolia and Kalamon cv.). The OC was collected using a 3 -stage oil mill and ensiled according to the method developed as follows. After olive oil extraction, crude OC was obtained immediately and accumulated on the surface of the clean, hard floor of the silos. The pile of OC that did not contain any additives or other feed materials for helping the fermentation process was covered with a black polyethylene film ( $8 \mathrm{~mm}$ thick) and firmly closed. The film covering the pile was stretched to expell the air, and soil was used to cover the edges of the film. The ensiled OC was fermented in the silos for 3 to 4 mo before use.

Dry matter intake was monitored daily during the last week of each experimental period. Animals of both groups were fed individually with automatic feeders (Westfalia, Albersdorf, Germany) offering the concentrates 4 times per day, and forages were divided and offered manually to each group after morning (0430 h) and evening $(1630 \mathrm{~h})$ milkings. The OC supplement was offered directly after morning milking, and cows consumed it entirely within about 15 min. Feeds were collected at the beginning and at the end of each experimental period and mixed per treatment, and a final sample was taken for analysis. Water was offered ad libitum. The chemical composition of the 2 treatments is presented in Table 1. Dry matter, ash, crude fat, and $\mathrm{CP}$ were determined as described by AOAC International (2005). Crude fiber, ADF, ADL, and amylase NDF were measured according to the method of Van Soest et al. (1991).

\section{Measurements and Milk Sampling}

All animals were machine milked (Fulwood, Shropshire, UK) twice daily (at 0430 and $1630 \mathrm{~h}$ ) and milk yields were recorded electronically (AfiMilk MPC Milk Meter, Kibbutz Afikim, Israel) at each milking, but only measurements taken the last week of each experimental period were analyzed statistically. Raw milk samples for the determination of the lipid profile were collected from each cow during the 2 consecutive milkings (morning and evening) at the end of each experimental period (wk 4 and wk 8) and were stored at $-80^{\circ} \mathrm{C}$ for further analysis. Measurements for total fat, protein, and SNF were obtained using combined thermo-optical procedures (Lactostar 3510, Funke Gerber, Berlin, Germany) calibrated previously for protein with the Lowry protein assay, and measurements for fat were obtained with the Gerber method 989.05 (AOAC International, 2005).

At the end of the second experimental period (wk 8), bulk milk obtained from cows of each treatment (CON and OC) was converted into 7 different Halloumi cheeses (14 samples total) according to the method of Papademas and Robinson (1998). Cheese samples were collected (250-300 g) from each barrel, placed in plastic bags, and vacuum-stored at $-20^{\circ} \mathrm{C}$ until analysis.

\section{Lipid Analysis}

The milk fat isolation was carried out according to the rapid double centrifugation method of Feng et

Table 1. Ingredients and chemical composition of dietary treatments and the olive cake silage used

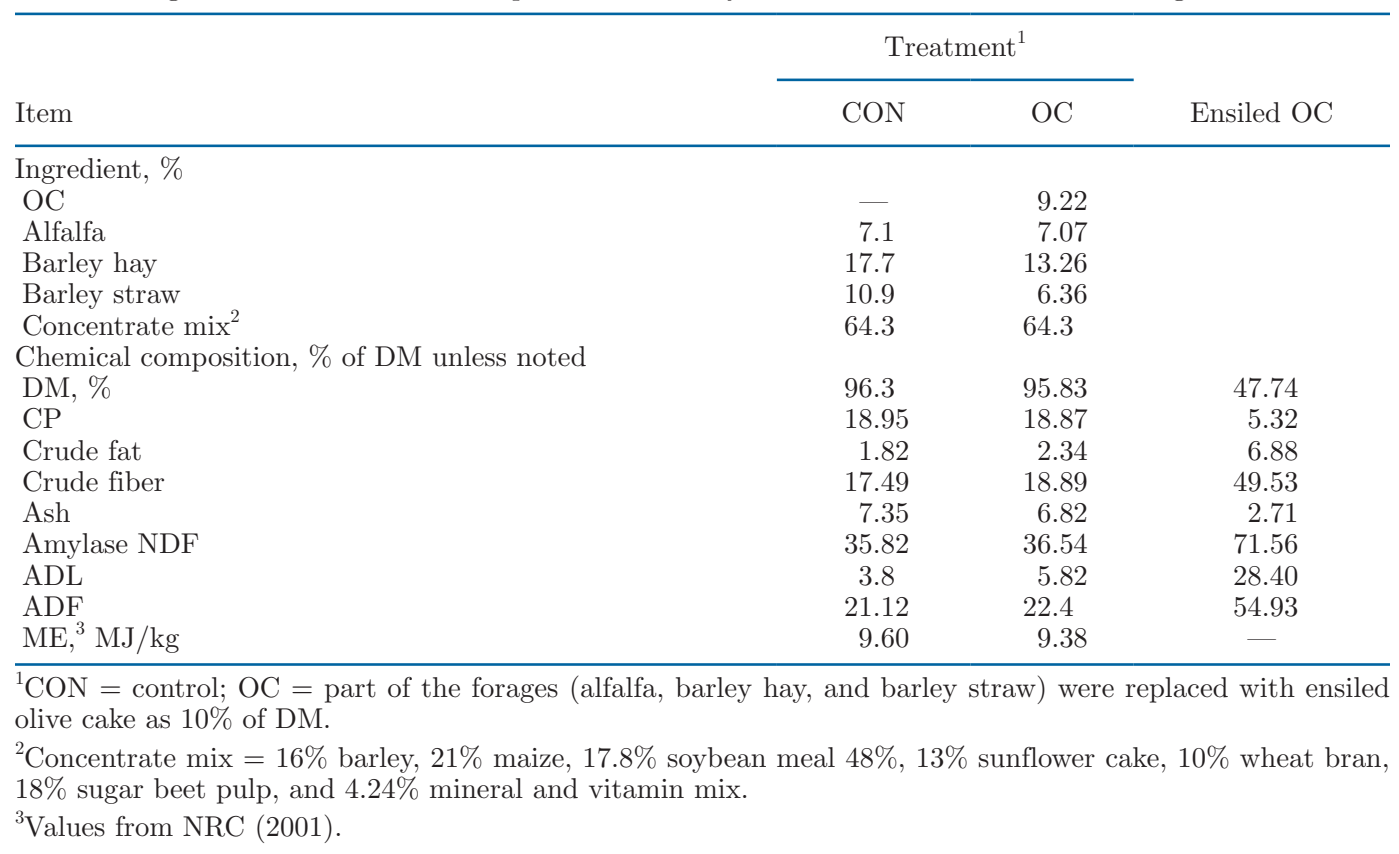


al. (2004) with slight modifications. Briefly, 20-mL aliquots of fresh milk were first centrifuged at 17,800 $\times g$ for $30 \mathrm{~min}$ at $4^{\circ} \mathrm{C}$. The resulting fat cakes were removed, placed in new tubes, and allowed to melt at room temperature for $20 \mathrm{~min}$. The samples were then recentrifuged at $19,500 \times g$ for $20 \mathrm{~min}$ at room temperature, and 20-mg aliquots of the resulting lipid cake were removed to fresh tubes and dispersed in $1 \mathrm{~mL}$ of $n$-hexane by shaking.

For the feed fat isolation, the method used was as follows. After crude fat determination (Soxtec method), $2 \mathrm{~mL}$ of hexane was added to the residue in the aluminum collection pots and transferred to a glass tube (pre-weighed). Then, the residue was dried down under a gentle stream of nitrogen gas, and the glass tube was reweighed. Subsequently, $1 \mathrm{~mL}$ of hexane was added for redissolving the residue, and then an aliquot containing 20 to $25 \mathrm{mg}$ of crude fat was removed and put into fresh tubes.

The cheese fat was extracted with diethyl ether as follows: $50 \mathrm{~mL}$ of diethyl ether and $0.5 \mathrm{~g}$ of $\mathrm{Na}_{2} \mathrm{SO}_{4}$ was added to 30 to $40 \mathrm{~g}$ of cheese samples and mixed vigorously. After $15 \mathrm{~min}$, the mixture was filtered through filter paper (Whatman no. 4, Sigma-Aldrich, St. Louis, MO) from a funnel. The filtrate was centrifuged for 2 min at $2,500 \times g$ at room temperature to remove the undesired particles that originated from cheese. The liquid phase of diethyl ether and oil was taken into a centrifuge test tube and diethyl ether was removed using a rotary evaporator at $40 \pm 1^{\circ} \mathrm{C}$. Then, the sample was flushed with nitrogen to remove the remaining ether from oil.

Fatty acid methyl esters of milk, Halloumi cheese, and feed lipids were prepared by transesterification with methanolic potassium hydroxide according to the ISO (2002) method. Essentially, $40 \mu \mathrm{L}$ of transesterification reagent $(11.2 \% \mathrm{KOH}$ in methanol) was added to the tubes containing extracted lipids from milk, cheese, and feeds and shaken vigorously for $1 \mathrm{~min}$. The tubes were then allowed to incubate for a further 5 min at room temperature before the addition of $0.1 \mathrm{~g}$ of sodium bisulfate. The particulate material was then removed by centrifugation at $350 \times g$ for $3 \mathrm{~min}$ at room temperature, and aliquots of the clear organic phase were transferred to amber gas chromatography vials and stored at $-70^{\circ} \mathrm{C}$ until analyzed. Fatty acid profiles were generated by analyzing the FAME samples on a GCMS-QP2010 Plus gas chromatography mass spectrometer (Shimadzu, Duisburg, Germany) equipped with an HT280T autosampler (HTA, Brescia, Italy) following the method of Kramer et al. (2008). Typically, $1-\mu \mathrm{L}$ aliquots of FAME were separated with a split ratio of 1:20 using an Agilent CP-Sil 88 fused silica capillary column $(100 \mathrm{~m} \times 0.25 \mathrm{~mm}$ i.d., $0.2 \mu \mathrm{m}$ film thickness $)$. The column was held for 4 min at $70^{\circ} \mathrm{C}$ after injection, increased at $13^{\circ} \mathrm{C} / \mathrm{min}$ to $175^{\circ} \mathrm{C}$, and then held at that temperature for a further $27 \mathrm{~min}$. The temperature was then raised to $215^{\circ} \mathrm{C}$ at $4^{\circ} \mathrm{C} / \mathrm{min}$, at which it was held for a further 36 min. Helium was the carrier gas at 1 $\mathrm{mL} / \mathrm{min}$, with both injector and interface temperatures of $225^{\circ} \mathrm{C}$. Chromatographic profiles were analyzed using Shimadzu GCMS Postrun Solution software, where individual peaks were identified by comparison of their retention indices with those of commercially available authentic standards (Supelco 37-FAME standard mix, cis-9,trans-11 CLA, trans-10,cis-12 CLA, C18:1 trans-11; Sigma-Aldrich, Gillingham, UK) using the National Institute of Standards and Technology 08 and 21 mass spectral libraries and cross referencing with chromatograms and spectrograms reported in the literature (Kramer et al., 2008; Tsiafoulis et al., 2014). All FAME peaks identified were quantitated by peak integration, and individual FAME were expressed as a percentage of the total fat (Butler et al., 2011).

The atherogenic index was determined in milk and Halloumi cheese using the formula proposed by Ulbricht and Southgate (1991):

$$
\begin{gathered}
\text { atherogenic index }=(\mathrm{C} 12: 0+4 \times \mathrm{C} 14: 0+\mathrm{C} 16: 0) / \\
(\Sigma \mathrm{MUFA}+\text { EPUFA }) .
\end{gathered}
$$

Desaturation index (DI) was determined in milk using the formula suggested by Garnsworthy et al. (2010):

$$
\begin{gathered}
\text { desaturation index }= \\
(\mathrm{C} 14: 1 \text { cis-9/C14:0 + C14:1 cis-9) } \times 100 .
\end{gathered}
$$

\section{Tissue Sampling for Expression Analysis}

At the end of the second experimental period (wk 8), 3 cows per treatment, randomly selected from each group, were transferred to an adjacent abattoir immediately after milking, and $50 \mathrm{~g}$ of perirenal and $50 \mathrm{~g}$ of mammary gland tissues were collected under sterile conditions (12 samples total). All samples were snapfrozen in liquid $\mathrm{N}_{2}$ immediately and stored at $-80^{\circ} \mathrm{C}$ until RNA extraction.

\section{Primer Design, RNA Extraction, Synthesis of cDNA, and Real-Time PCR}

Primer design was performed using the PrimerBLAST tool at the National Center for Biotechnology Information (NCBI; Bethesda, MD) platform using mRNA (preferably reference where available) sequences 
for each target or housekeeping gene obtained from the NCBI database (Table 2). Total RNA from perirenal adipose $(25 \mathrm{mg})$ and mammary gland $(50 \mathrm{mg})$ tissue was isolated using NucleoZOL reagent (Macherey-Nagel GmbH \& Co. KG, Düren, Germany) following the manufacturer's instructions. Briefly, 25 or $50 \mathrm{mg}$ of tissue were homogenized in $500 \mu \mathrm{L}$ of NucleoZOL reagent. Adipose tissue samples were centrifuged at 12,000 $\times g$ for $5 \mathrm{~min}$ at room temperature, and supernatant below the fatty layer was transferred into a new tube. Then, $200 \mu \mathrm{L}$ of RNase-free water was added, and samples were vortexed and incubated at room temperature for $15 \mathrm{~min}$ and then centrifuged at $12,000 \times g$ for 15 min. Supernatants $(500 \mu \mathrm{L})$ were mixed with $500 \mu \mathrm{L}$ of isopropanol, incubated at room temperature for 10 min, and then centrifuged at $12,000 \times g$ for $10 \mathrm{~min}$ at room temperature. Pellets were washed twice with $75 \%$ ethanol and centrifuged at $8,000 \times g$ for 3 min at room temperature. Finally, pellets were air-dried and diluted in $60 \mu \mathrm{L}$ of RNase free water and samples were stored at $-80^{\circ} \mathrm{C}$ for further analysis. The RNA purity $(260 / 280$ and $260 / 230)$ and concentration $(\mathrm{ng} / \mu \mathrm{L})$ were assessed using a micro-volume UV spectrophotometer (Quawell Spectrophotometer 3000, Lab Supplies Scientific, San Jose, CA). The cDNA was synthesized from $1 \mu \mathrm{g}$ of total RNA in $20-\mu \mathrm{L}$ reactions using the PrimeScript RT-PCR reagent kit (Takara Bio Inc., Shiga, Japan) according to the manufacturer's instructions, and samples were stored at $-20^{\circ} \mathrm{C}$ for further analysis.

The mRNA abundance of 11 candidate genes, shown in Table 2, was assessed via quantitative real-time reverse-transcription PCR (RT-qPCR). To account for variation in RNA integrity, RNA quantification, and cDNA synthesis, the mRNA abundance was normalized using the geometric mean of 3 reference genes [ubiquitously expressed transcript $(U X T)$, ribosomal protein S9 (RPS9), and ribosomal protein S15 (RPS15)], which have been recommended as the most suitable reference genes in the bovine mammary gland during lactation (Bionaz and Loor, 2007).

The RT-qPCR reactions were performed in an ABI 7500 Real-Time PCR system (Applied Biosystems, Darmstadt, Germany) using FastGene IC Green $2 \times$ Universal Mix (Bioline, London, UK). Each 10- $\mu \mathrm{L}$ reaction contained $1.0 \mu \mathrm{L}$ of $\mathrm{cDNA}$ (synthesized from $\sim 12.5 \mathrm{ng}$ of total RNA), $400 \mathrm{nM}$ forward and reverse primer, and $5.0 \mu \mathrm{L}$ of IC Green Master Mix (Bioline). The RT-qPCR analyses of each studied gene were performed using cDNA from 6 biological replicates, with 3 technical replicates per biological replicate. The qPCR thermal protocol used was as follows: 1 cycle of $95^{\circ} \mathrm{C}$ for $2 \mathrm{~min}, 40$ cycles of $95^{\circ} \mathrm{C}$ for $5 \mathrm{~s}, 60^{\circ} \mathrm{C}$ for $30 \mathrm{~s}$, and $95^{\circ} \mathrm{C}$ for $30 \mathrm{~s}$. This was followed by a melt-curve analysis to ensure specific amplification. Real-time PCR runs with efficiencies between 86 and $110 \%$ were considered acceptable and used for data analysis.

Data were analyzed using the 7500 Fast Software option for quantitation-relative standard curve with SYBR green reagents (version 2.3; Applied Biosystems). Threshold cycle $\left(\mathbf{C}_{\mathbf{T}}\right)$ values were obtained for each reaction using the automatic $\mathrm{C}_{\mathrm{T}}$ option in which the software calculates the baseline start and end values and the threshold in the amplification plot for a set of reactions. The software uses the baseline and threshold to calculate the $\mathrm{C}_{\mathrm{T}}$ for each reaction. To perform relative quantitation of mRNA levels for each gene, a set of standards, consisting of 5-point serial dilutions (1:1, $1: 3,1: 3^{2}, 1: 3^{3}$, and $\left.1: 3^{4}\right)$ of cDNA prepared from a pool of cDNA from adipose and mammary tissue, were used along with the samples at every qPCR run. Results from the standards reactions (triplicates for each dilution point) were used to generate the relative standard curve for each gene under study. The corresponding standard curve was identified as the best-fit regression line of $\mathrm{C}_{\mathrm{T}}$ (dependent variable, values obtained from the reactions as described above) on the $\log ($ Qty) [independent variable with values $\log (1), \log (1 / 3), \log \left(1 / 3^{2}\right)$, $\log \left(1 / 3^{3}\right)$, and $\left.\log \left(1 / 3^{4}\right)\right]$ described by the regression line formula $C_{T}=m[\log (Q t y)]+b$, where $m$ is the slope, $\mathrm{b}$ is the y-intercept, and Qty is the relative mRNA level of the gene (quantity). Relative mRNA levels for each gene and biological sample were estimated as the mean Qty of 3 technical replicates, obtained using the regression formula mentioned above and applying the $\mathrm{C}_{\mathrm{T}}$ values obtained from the reactions as described above.

\section{Statistical Analysis}

All data at the animal level from the two 28-d experimental periods were subjected to an analysis of a $2 \times 2$ AB-BA crossover design (Kaps and Lamberson, 2009) using SAS software (version 9.4, SAS Institute Inc., Cary, NC) to test the effects of the OC feeding treatment. The statistical model included the fixed effects of period, experimental diet, and sequence (the order in which treatments were allocated to each animal). Differences between the diet means were tested based on least squares means difference and declared significant when the $P$-value was less than 0.05 . $P$-values between 0.05 and 0.10 were interpreted as a trend toward significance.

The FA content in Halloumi cheese and feeds results were subjected to a 2-group $t$-test with 7 and 3 replications, respectively. The normalized relative mRNA expression data were subjected to nonparametric 1-way ANOVA using SAS Studio software (university edition, version 3.8, SAS Institute Inc.) because data were not normally distributed. For each gene, the dependent 
Neofytou et al.: FEEDING ENSILED OLIVE CAKE IN DAIRY COWS

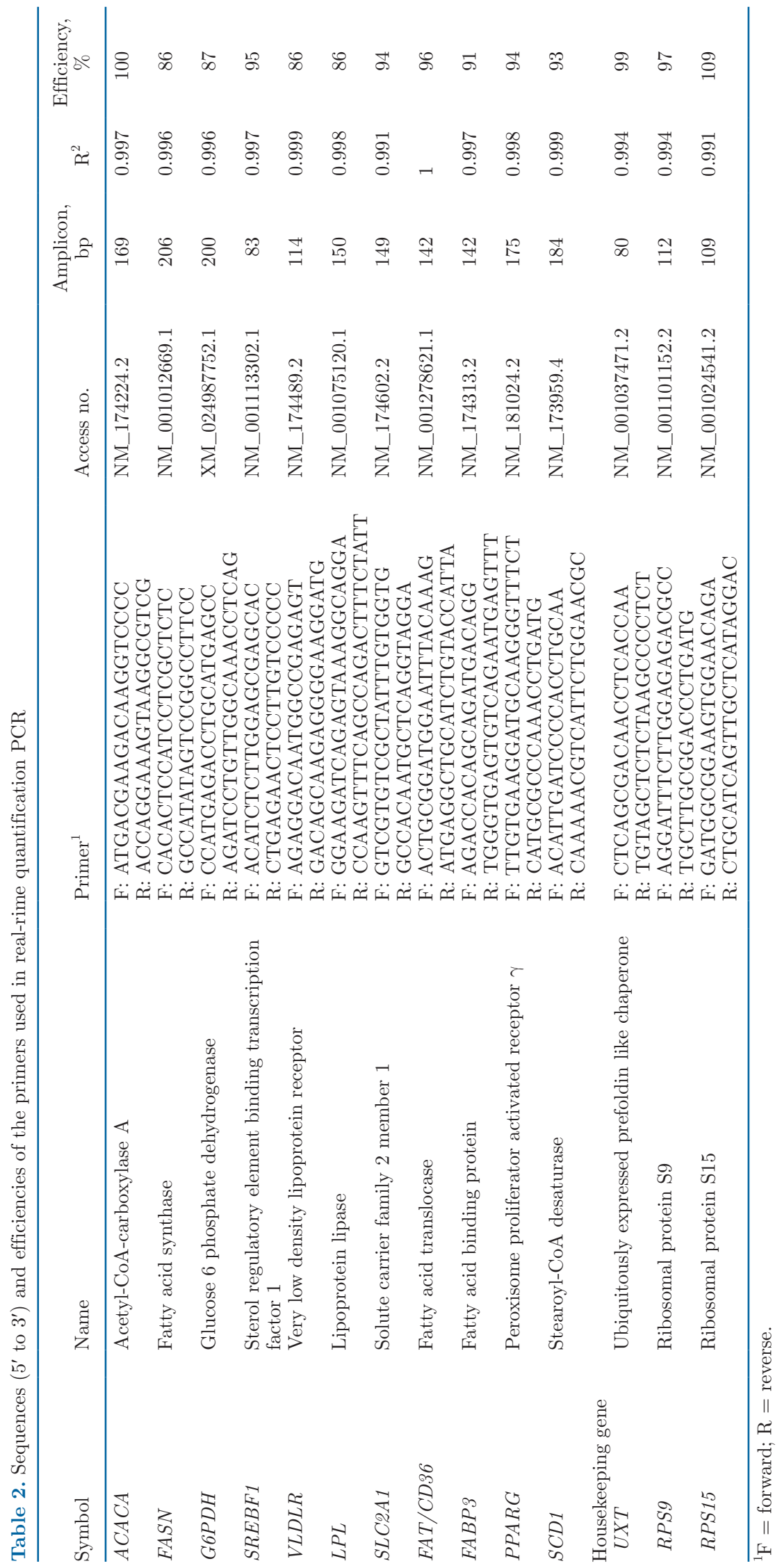


Table 3. Fatty acid composition (expressed as a percentage of total FAME) of the dietary treatments used and ensiled olive cake (OC)

\begin{tabular}{|c|c|c|c|c|c|}
\hline \multirow[b]{2}{*}{ Item } & \multicolumn{2}{|c|}{ Treatment $^{1}$} & \multirow[b]{2}{*}{ SEM } & \multirow[b]{2}{*}{$P$-value } & \multirow[b]{2}{*}{ Ensiled OC } \\
\hline & $\mathrm{CON}$ & $\mathrm{OC}$ & & & \\
\hline C12:0 & 1.05 & 0.68 & 0.09 & $*$ & - \\
\hline C14:0 & 1.55 & 0.85 & 0.19 & NS & - \\
\hline C16:0 & 26.83 & 23.35 & 0.81 & $* *$ & 13.45 \\
\hline C16:1 cis-9 & 0.25 & 0.57 & 0.07 & $* *$ & 1.48 \\
\hline C18:0 & 2.04 & 2.58 & 0.12 & $* * *$ & 4.15 \\
\hline C18:1 cis-9 & 21.16 & 33.30 & 2.73 & $* * *$ & 63.58 \\
\hline C18:2n-6 & 23.52 & 21.39 & 0.51 & $* *$ & 13.12 \\
\hline C18:3n-3 & 2.23 & 1.68 & 0.18 & NS & 1.46 \\
\hline
\end{tabular}

$\overline{{ }^{1} \mathrm{CON}}=$ control; $\mathrm{OC}=$ part of the forages (alfalfa, barley hay, and barley straw) were replaced with ensiled olive cake as $10 \%$ of DM.

${ }^{*} P<0.05 ;{ }^{* *} P<0.01 ;{ }^{* * *} P<0.001$.

variable was the relative normalized mRNA expression level (12 biological replicates, 6 per treatment group) and the classification variable was the treatment group ( 2 treatment groups: control and OC). Differences between treatment means were tested based on Wilcoxon scores followed by Kruskal-Wallis test with $\mathrm{df}=1$ and were declared significant when $P<0.05$.

\section{RESULTS}

\section{OC Silage and Diets}

The FA composition of OC silage and diets is shown in Table 3. The inclusion of $\mathrm{OC}$ in the diets had significant effects on most FA. Oleic acid (C18:1 cis-9; $P<0.001)$ was the major FA found, at a concentration of around $30 \%$ of the dietary lipids of the OC-supplemented diet. Palmitic (C16:0; $P<0.01)$ and linoleic $(\mathrm{C} 18: 2 \mathrm{n}-6 ; P<$ $0.01)$ acids were also abundant, whereas stearic (C18:0; $P<0.001)$ and linolenic (C18:3n-3) acids were found in lesser quantities in both treatments. The OC diet showed a significantly lower content of palmitic and linoleic acids compared with the CON diet. In contrast, an increased proportion of stearic acid in the $\mathrm{OC}$ diet was demonstrated.

\section{Performance Variables of Cows}

Table 4 shows the DMI, milk production and yield, fat and protein yields, and composition of the milk samples after 4 wk of supplementation. Supplementation with OC did not influence the milk and protein yields or the milk composition of the cows during the trial. However, fat yield was greater $(P<0.05)$ in the OC group than in the CON group, and the fat content tended to be higher in the OC group $(P=0.087)$. No differences were observed in SNF, milk production, or DMI measurements.

\section{Milk FA Composition}

The percentages of analyzed FA and their aggregated groups determined in milk collected from $\mathrm{CON}$ and OC-treated animals are given in Table 5. The inclusion of OC to the diet of lactating cows significantly increased 18-carbon atom FA content at the expense of a decrease in de novo FA $(\mathrm{C}<16)$ concentration. Total SFA as well as individual SFA such as C14:0 and C16:0 were decreased, whereas C18:0 was increased by the addition of $\mathrm{OC}$ in the cow diets. Concentrations of the 18-C MUFA, such as oleic acid (C18:1 cis-9), as well as the sum of $\mathrm{C} 18: 1$ trans-10 and trans-11 were significantly higher in the milk of cows that consumed OC compared with the milk of the CON group. Regarding other MUFA, the content of C14:1 cis-9 and C16:1 cis-9 acids was reduced and C10:1 cis-9 was not affected by the inclusion of $\mathrm{OC}$ in the cow diets.

Although no differences in the concentrations of total PUFA were observed between treatments, it is important to mention that milk from the OC group contained a significantly higher concentration of ru-

Table 4. Milk production and chemical composition of milk from cows fed diets with 0 or 10\% (DM basis) inclusion of ensiled olive cake for a 4 -wk period

\begin{tabular}{lrrrc}
\hline & \multicolumn{2}{c}{ Treatment $^{1}$} & & \\
\cline { 2 - 3 } Item & CON & OC & SEM & $P$-value \\
\hline DMI, kg/d & 25.58 & 25.56 & 1.55 & NS \\
Milk yield, kg/d & 24.48 & 25.27 & 1.29 & NS \\
Fat yield, kg/d & 0.80 & 0.85 & 0.05 & $*$ \\
Protein yield, kg/d & 0.86 & 0.89 & 0.04 & NS \\
Milk composition, $\%$ & & & & \\
Fat & 3.29 & 3.40 & 0.08 & $\dagger$ \\
Protein & 3.52 & 3.53 & 0.02 & NS \\
SNF & 8.62 & 8.63 & 0.03 & NS \\
\cline { 1 - 2 } CON & & &
\end{tabular}

${ }^{1} \mathrm{CON}=$ control; $\mathrm{OC}=$ part of the forages (alfalfa, barley hay, and barley straw) were replaced with ensiled olive cake as $10 \%$ of DM. ${ }^{*} P<0.05 ; \dagger P<0.1$ (tendency). 
Table 5. Fatty acid composition (expressed as a percentage of total FAME) of milk from cows fed a diet with 0 or $10 \%$ (DM basis) inclusion of ensiled olive cake for a 4 -wk period

\begin{tabular}{|c|c|c|c|c|}
\hline \multirow[b]{2}{*}{ Item } & \multicolumn{2}{|c|}{ Treatment $^{1}$} & \multirow[b]{2}{*}{ SEM } & \multirow[b]{2}{*}{$P$-value } \\
\hline & $\mathrm{CON}$ & $\mathrm{OC}$ & & \\
\hline $\mathrm{C} 4: 0$ & 3.27 & 3.23 & 0.14 & NS \\
\hline C6:0 & 2.03 & 2.01 & 0.05 & NS \\
\hline C8:0 & 1.27 & 1.22 & 0.06 & NS \\
\hline C10:0 & 2.96 & 2.65 & 0.16 & NS \\
\hline $\mathrm{C} 10: 1$ cis-9 & 0.33 & 0.29 & 0.01 & NS \\
\hline C12:0 & 3.46 & 3.00 & 0.18 & NS \\
\hline C13:0 iso & 0.14 & 0.12 & 0.009 & NS \\
\hline C14:0 & 11.50 & 10.22 & 0.27 & * \\
\hline C14:1 cis-9 & 1.44 & 1.17 & 0.06 & $*$ \\
\hline C15:0 & 0.99 & 0.86 & 0.04 & $\dagger$ \\
\hline C15:0 iso & 0.25 & 0.27 & 0.03 & NS \\
\hline C16:0 & 34.77 & 30.88 & 0.50 & $* *$ \\
\hline C16:1 cis-9 & 1.96 & 1.51 & 0.06 & $* *$ \\
\hline C17:0 ante/iso & 0.49 & 0.39 & 0.04 & $\dagger$ \\
\hline C17:0 & 0.49 & 0.48 & 0.03 & NS \\
\hline C18:0 & 8.61 & 11.76 & 0.29 & $* * *$ \\
\hline C18:1 cis-9 & 18.32 & 22.17 & 0.41 & $* *$ \\
\hline C18:1 cis-11 & 0.46 & 0.61 & 0.03 & $*$ \\
\hline $\mathrm{C} 18: 1$ trans $-10+$ trans $-11^{2}$ & 0.66 & 0.92 & 0.07 & $*$ \\
\hline $\mathrm{C} 18: 2 \mathrm{n}-6$ & 3.55 & 3.56 & 0.32 & NS \\
\hline cis-9,trans-11 CLA & 0.59 & 0.65 & 0.006 & $*$ \\
\hline trans-10, cis-12 CLA & 0.26 & 0.31 & 0.06 & NS \\
\hline C18:3n-3 & 0.64 & 0.47 & 0.16 & NS \\
\hline $\mathrm{C} 20: 3 n-6$ & 0.71 & 0.65 & 0.08 & NS \\
\hline $\mathrm{C} 20: 4 n-6$ & 0.92 & 0.85 & 0.08 & NS \\
\hline \multicolumn{5}{|l|}{ Sum } \\
\hline $\mathrm{SCFA}^{3}$ & 9.68 & 9.41 & 0.21 & NS \\
\hline $\mathrm{MCFA}^{4}$ & 54.81 & 48.09 & 0.15 & $* * *$ \\
\hline $\mathrm{LCFA}^{5}$ & 34.55 & 41.68 & 0.12 & $* * *$ \\
\hline$<\mathrm{C} 16: 0$ & 27.81 & 25.07 & 0.60 & $*$ \\
\hline$>\mathrm{C} 16: 0$ & 34.99 & 41.97 & 0.08 & $* * *$ \\
\hline SFA & 70.54 & 67.07 & 0.38 & $* *$ \\
\hline MUFA & 23.12 & 26.49 & 0.62 & $* *$ \\
\hline PUFA & 6.31 & 6.29 & 0.42 & NS \\
\hline Atherogenic index ${ }^{6}$ & 2.93 & 2.33 & 0.06 & $* * *$ \\
\hline Desaturation index ${ }^{7}$ & 11.13 & 10.06 & 0.39 & NS \\
\hline
\end{tabular}

${ }^{1} \mathrm{CON}=$ control; $\mathrm{OC}=$ part of the forages (alfalfa, barley hay, and barley straw) were replaced with ensiled olive cake as 10\% of DM.

${ }^{2}$ Sum of C18:1 trans-10 and trans-11.

${ }^{3}$ Short-chain fatty acids (C4:0 to C10:1 cis-9).

${ }^{4}$ Medium-chain fatty acids (C12:0 to C16:1 cis-9).

${ }^{5}$ Long-chain fatty acids (C17:0 to C20:4n-6).

${ }^{6}$ Atherogenic index $=(\mathrm{C} 12: 0+4 \times \mathrm{C} 14: 0+\mathrm{C} 16: 0) /(\Sigma \mathrm{MUFA}+$ इPUFA).

${ }^{7}$ Desaturation index $=(\mathrm{C} 14: 1$ cis-9 $/ \mathrm{C} 14: 0+\mathrm{C} 14: 1$ cis-9 $) \times 100$.

${ }^{*} P<0.05$; ${ }^{* *} P<0.01$; *** $P<0.001 ; \dagger P<0.1$ (tendency).

menic acid (RA; cis-9,trans-11 CLA) compared with the CON group. However, similar FA content between treatments was observed in trans-10,cis-12 CLA as well as in linoleic (C18:2n-6), $\alpha$-linolenic (C18:3n-3), and arachidonic (C20:4n-6) acids. The inclusion of OC reduced milk atherogenic index, whereas desaturation index did not differ between treatments. Overall, the differences in the concentrations of individual FA are reflected in differences between the short-chain FA (SCFA), medium-chain FA (MCFA), and long-chain
FA (LCFA), in which OC supplementation reduced MCFA and increased LCFA compared with the CON group, whereas no diet effects were observed on SCFA percentages of milk fat (Table 5).

\section{FA Composition of Halloumi Cheese}

The mean percentages of the different FA in Halloumi cheese and the aggregated groups of FA are presented in Table 6. Results showed that Halloumi FA composition was similar to milk FA composition and likewise affected by treatment. Halloumi cheese produced using OC milk contained more 18C FA compared with the cheese of the CON group. At the same time, the percentage of total SFA was decreased $(P<0.01)$ by the addition of olive by-product because the OC group appeared to have lower values than the CON treatment.

There was no diet effect on C16:1 cis-9, C14:1 cis-9, and MCFA, whereas SCFA were decreased in Halloumi cheese produced by the milk of the OC group. In accordance with milk FA results, MUFA of Halloumi cheese was increased by inclusion of OC. Among individual MUFA, the OC diet increased oleic acid (C18:1 cis-9) and the sum of C18:1 trans-10 and trans-11 acids and decreased the content of $\mathrm{C} 10: 1$ cis-9 acid.

Regarding PUFA, the average percentage of linoleic acid (C18:2n-6) and cis-9,trans-11 CLA in Halloumi cheese from cows of the OC-supplemented group was increased compared with the CON group. In line with these results, LCFA in Halloumi cheese increased with OC addition compared with the CON group $(P<0.05)$. In contrast, $\mathrm{OC}$ inclusion did not modify the percentages of C18:3n-3, C20:4n-6, C20:3n-6, and total PUFA. Finally, a reduced proportion in atherogenic index was observed in the Halloumi cheese produced with the OC milk (Table 6).

\section{Gene Expression}

The mRNA abundance of candidate genes is presented in Figures 1 and 2 for mammary gland and adipose tissues, respectively. In adipose tissue, mRNA expression of SREBF1 was upregulated in cows fed the OCsupplemented diet. No significant effects were observed in the expression of any of the other genes examined in perirenal fat or in the transcriptional expression of any of the 11 genes analyzed in mammary tissues.

\section{DISCUSSION}

The current study was designed to investigate whether partly replacing forages in cow diets with OC silage as $10 \%$ of DM based on previous expertise (Hadjipanayiotou, 1999, and Agricultural Research 
Institute, Nicosia, Cyprus, personal communication) could improve the milk lipid profile without reducing intake or inducing milk fat depression. Indeed, supplementing the diets of lactating cows with OC did not significantly affect milk fat content similarly to other studies (Hadjipanayiotou, 1999; Meo Zilio et al., 2014; Castellani et al., 2017), whereas an increase in fat yield was demonstrated. In cattle, OC feeding up to $15 \%$ on a DM basis did not significantly affect milk fat yield (Hadjipanayiotou, 1999; Meo Zilio et al., 2014). However, in accordance with our study, Castellani et al.

Table 6. Fatty acid composition (expressed as a percentage of total FAME) of Halloumi cheeses made with raw milk from cows fed a diet with 0 or $10 \%$ (DM basis) inclusion of ensiled olive cake for a 4 -wk period

\begin{tabular}{|c|c|c|c|c|}
\hline \multirow[b]{2}{*}{ Item } & \multicolumn{2}{|c|}{ Treatment $^{1}$} & \multirow[b]{2}{*}{ SEM } & \multirow[b]{2}{*}{$P$-value } \\
\hline & $\mathrm{CON}$ & $\mathrm{OC}$ & & \\
\hline C4:0 & 3.48 & 2.34 & 0.18 & ** \\
\hline C5:0 & 0.11 & 0.05 & 0.05 & NS \\
\hline C6:0 & 3.69 & 2.4 & 0.08 & $* * *$ \\
\hline C8:0 & 3.03 & 1.32 & 0.06 & $*$ \\
\hline C9:0 & 0.14 & 0.06 & 0.03 & NS \\
\hline C10:0 & 4.41 & 2.27 & 0.06 & $*$ \\
\hline C10:1 cis-9 & 0.72 & 0.44 & 0.01 & $*$ \\
\hline C12:0 & 3.70 & 3.71 & 0.03 & NS \\
\hline $\mathrm{C} 12: 1$ cis-9 & 0.11 & 0.12 & 0.01 & NS \\
\hline C13:0 & 0.48 & 0.37 & 0.06 & NS \\
\hline C14:0 & 9.31 & 9.32 & 0.16 & NS \\
\hline C14:1 cis-9 & 1.58 & 1.38 & 0.07 & NS \\
\hline C15:0 iso & 0.21 & 0.52 & 0.12 & NS \\
\hline C15:0 & 2.40 & 1.85 & 0.02 & $*$ \\
\hline C16:0 & 25.13 & 26.49 & 0.19 & NS \\
\hline C16:1 cis-9 & 2.59 & 2.37 & 0.09 & NS \\
\hline $\mathrm{C} 17: 0$ & 0.74 & 0.66 & 0.12 & NS \\
\hline $\mathrm{C} 17: 0$ ante/iso & 0.66 & 0.53 & 0.10 & NS \\
\hline $\mathrm{C} 17: 1$ cis-9 & 1.28 & 1.13 & 0.11 & NS \\
\hline C18:0 & 7.17 & 10.18 & 0.02 & $* * *$ \\
\hline $\mathrm{C} 18: 1$ trans $-10+$ trans $-11^{2}$ & 0.46 & 0.91 & 0.02 & $* *$ \\
\hline C18:1 cis-9 & 18.53 & 21.53 & 0.67 & *** \\
\hline C18:2n-6 & 2.65 & 3.26 & 0.21 & $*$ \\
\hline cis-9,trans-11 CLA & 0.36 & 0.66 & 0.01 & * \\
\hline C18:3n-3 & 0.56 & 0.57 & 0.02 & NS \\
\hline $\mathrm{C} 20: 3 \mathrm{n}-6$ & 0.17 & 0.17 & 0.02 & NS \\
\hline $\mathrm{C} 20: 4 \mathrm{n}-6$ & 0.26 & 0.31 & 0.02 & NS \\
\hline \multicolumn{5}{|l|}{ Sum } \\
\hline $\mathrm{SCFA}^{3}$ & 15.81 & 8.93 & 0.67 & $* *$ \\
\hline $\mathrm{MCFA}^{4}$ & 45.60 & 45.87 & 0.47 & NS \\
\hline $\mathrm{LCFA}^{5}$ & 33.15 & 40.06 & 1.56 & $* * *$ \\
\hline SFA & 64.90 & 61.85 & 0.88 & $*$ \\
\hline MUFA & 25.47 & 27.90 & 0.55 & *** \\
\hline PUFA & 4.10 & 4.88 & 0.20 & NS \\
\hline Atherogenic index ${ }^{6}$ & 2.24 & 2.06 & 0.04 & $*$ \\
\hline
\end{tabular}

${ }^{1} \mathrm{CON}=$ control; OC $=$ part of the forages (alfalfa, barley hay, and barley straw) were replaced with ensiled olive cake as $10 \%$ of DM.

${ }^{2}$ Sum of C18:1 trans-10 and trans- 11 .

${ }^{3}$ Short-chain fatty acids (C4:0 to C10:1 cis-9).

${ }^{4}$ Medium-chain fatty acids (C12:0 to C16:1 cis-9).

${ }^{5}$ Long-chain fatty acids (C17:0 to C20:4n-6).

${ }^{6}$ Atherogenic index $=(\mathrm{C} 12: 0+4 \times \mathrm{C} 14: 0+\mathrm{C} 16: 0) /(\Sigma \mathrm{MUFA}+$ SPUFA).

${ }^{*} P<0.05 ;{ }^{* *} P<0.01 ;{ }^{* * *} P<0.001$.
(2017) found a tendency of increased fat percentage. Although results for fat yield were not reported in that study, higher levels of fat content could have increased fat yield due to the similar milk production reported. In addition, a meta-analysis evaluating the effect of adding free fat or oil supplements in cow diets showed that the effect of dietary lipid profile can be either positive or negative or without any significant difference in milk fat yield, although affecting the FA profile of milk (Dorea and Armentano, 2017).

In the present study, the inclusion of $\mathrm{OC}$ in the diets of lactating cows did not affect milk yield, as expected from using isoenergetic and isonitrogenous diets reported previously (Hadjipanayiotou, 1999; Meo Zilio et al., 2014; Castellani et al., 2017), or affect protein content or yield, as has also been found by others (Hadjipanayiotou, 1999; Meo Zilio et al., 2014). Although Castellani et al. (2017) observed that milk protein content was influenced by the integration of dried olive pomace into cow diets, the authors attributed the unexpected results to the difference in the forage: concentrate ratio of the diets.

In our study, addition of ensiled OC in the diets of dairy cows altered milk FA composition and affected individual FA with positive effects for human health. Levels of LCFA and particular FA with 18 carbon atoms such as oleic (C18:1 cis-9) and cis-9,trans-11 CLA were increased, whereas total SFA (particularly C14:0 and $\mathrm{C} 16: 0)$ and, consequently, the atherogenic index were decreased significantly.

The proportion of FA with less than 16 carbons was significantly reduced by replacing part of the forages with ensiled OC. Those results are in line with previous studies that reported reduced de novo FA content, particularly decreased concentration of MCFA, and increased levels of LCFA by addition of a high level of unsaturated 18C FA in cow diets (reviewed in Dorea and Armentano, 2017), as is the case of diets rich in oleic acid in the present and previous studies (He et al., 2012; Castellani et al., 2017; Weld and Armentano, 2018). This could be attributed to a higher uptake of LCFA from the blood or a lower de novo synthesis of FA in the mammary gland (Chilliard et al., 2000; Dorea and Armentano, 2017). The de novo FA synthesis could be inhibited by bioactive FA, including trans monoenes and CLA such as trans-10,cis-12 CLA (Bauman et al., 2006,2011 ), which was not, however, significantly different between the 2 examined groups in the present study. The decreased MCFA and C $<16$ FA, indicative of decreased de novo FA synthesis, could possibly be attributed to isomerization of oleic acid into trans monoenes such as C18:1 trans-10 and trans-11 (Dorea and Armentano, 2017) found significantly elevated in the milk of cows fed ensiled OC in our study; C18:1 


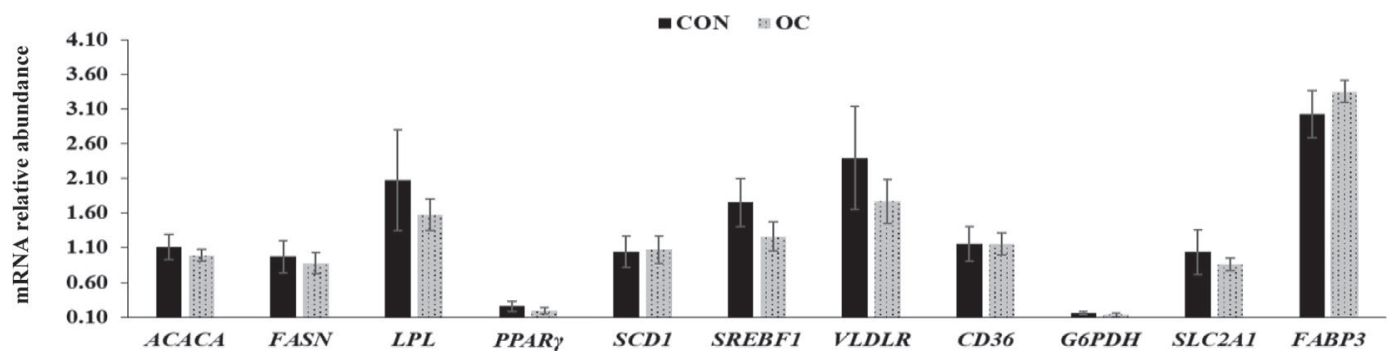

Figure 1. The mRNA relative abundance (mean $\pm \mathrm{SEM}$ ) of lipogenic genes and transcription factors of the mammary tissue in dairy cows fed a control diet (CON; solid black bars) or the control diet supplemented with ensiled olive cake as $10 \%$ of DM (OC; dotted gray bars). The mRNA levels are expressed as abundance relative to the geometric mean of UXT, RPS9, and RPS15 mRNA.

trans-10 is strongly associated with milk fat depression in cows (Gaynor et al., 1994; Griinari et al., 1998; Shingfield et al., 2009). Although we did not observe a low-fat syndrome, the concentration of FA with less than 16 carbons is a better indicator of inhibition of milk FA secretion compared with milk fat content due to the possible masking effect of the exogenous supply of 18C dietary FA (Dorea and Armentano, 2017). Therefore, both a higher uptake of dietary LCFA and decreased de novo synthesis of MCFA in the mammary glands of cows fed ensiled OC, without affecting milk fat percentage, are possible mechanisms.

Among SFA, a significant increase of stearic acid (C18:0) was observed in milk by OC diet inclusion, which is consistent with previous studies indicating increased levels of C18:0 (He et al., 2012; Castellani et al., 2017) in milk due to high levels of UFA 18C FA in dairy cattle diets. Stearic acid is the final product of biohydrogenation (BH) of dietary MUFA and polyunsaturated $\mathrm{C} 18 \mathrm{FA}$, resulting from microbial $\mathrm{BH}$ saturation of double bonds in LCFA (Shingfield et al., 2010; Ferlay et al., 2017), such as oleic acid, which was abundant in the $\mathrm{OC}$ diet.
The reduction of SFA in the present study was accompanied by increased total MUFA content in the OC-supplemented group. Similar effects and patterns have been found by researchers who tested diets supplemented with various forms of processed OC in ewes (Chiofalo et al., 2004; Abbeddou et al., 2011a,b, 2015; Vargas-Bello-Pérez et al., 2013; Symeou et al., 2019), goats (Molina-Alcaide et al., 2010), and cows (Castellani et al., 2017). Addition of olive oil in cow diets also led to similar findings (Vargas-Bello-Pérez et al., 2018). It is likely that MUFA of feed, escaping BH, were transferred to milk FA content through mammary uptake from the plasma dietary FA, contributing to the higher MUFA content of milk (Shingfield et al., 2010). In addition, feeding unprotected oils, rich in 18C PUFA, increases both C18:1 and C18:2 cis and trans isomers arising from ruminal metabolism and from mammary desaturation of $\mathrm{C} 18: 0$ and $\mathrm{C} 18: 1$ trans (mainly 7 and 11) produced in the rumen (Chilliard et al., 2000). Indeed, milk C18:1 cis-9 can be generated either through the action of mammary $\Delta^{9}$-desaturase with the substrate being stearic acid or by direct transfer from feed (Collomb et al., 2006; Chilliard et al.,

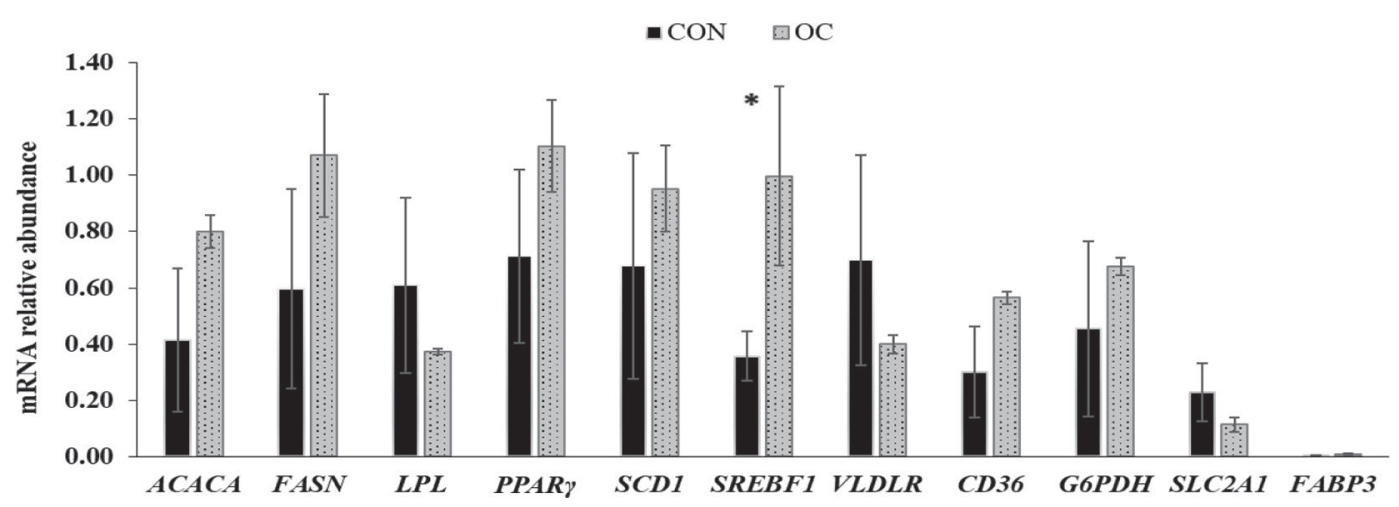

Figure 2. The mRNA relative abundance (mean \pm SEM) of lipogenic genes and transcription factors of the adipose tissue in dairy cows fed a control diet (CON; solid black bars) or the control diet supplemented with ensiled olive cake as $10 \%$ of DM (OC; dotted gray bars). The mRNA levels are expressed as abundance relative to the geometric mean of UXT, RPS9, and RPS15 mRNA. Within each gene, * indicates significant differences $(P<0.05)$ between the experimental treatments. 
2007). However, because the $\Delta^{9}$-desaturation index in the mammary gland did not differ between groups in the current study, it can be assumed that the increase in oleic acid is probably related more to the diet than to $\Delta^{9}$-desaturase activity.

In the present study, only RA and trans-10, cis-12 CLA isomers were detectable, from which the former was significantly increased in the milk fat of cows fed the OC diet, whereas the latter did not differ between treatments. Previous studies in cows observed significantly higher contents for both CLA isomers by the addition of dried olive pomace (Castellani et al., 2017) and olive oil (Vargas-Bello-Pérez et al., 2018), whereas in line with our study, He et al. (2012) reported increased levels only for RA by addition of high oleic-rich diets in cows compared with the control group. It is well known that the majority of RA in milk fat is synthesized endogenously in the mammary gland through the action of mammary $\Delta^{9}$-desaturase with the substrate being vaccenic acid, whereas a small amount of this specific CLA originates from BH of UFA by rumen bacteria (Lock and Bauman, 2004; Collomb et al., 2006; Buccioni et al., 2012). Thus, the elevated proportions of RA observed in the milk of the OC group could be due either to the higher concentrations of vaccenic acid in the mammary gland compared with CON group or to the incomplete $\mathrm{BH}$ taking place in the rumen of cows fed the OC diet (Bauman et al., 2006).

Interestingly, the effects of OC treatment in the FA composition of Halloumi cheese were similar to those observed in milk. This suggests that the improvement in nutritional quality achieved in milk because of OC supplementation is thereafter largely maintained in Halloumi cheese. Similarly to the FA profile of milk, reduced levels of SFA and significantly increased levels of LCFA and MUFA were observed in Halloumi cheese when OC was supplemented in cow diet, and, consequently, atherogenic index was diminished. Both milk and Halloumi cheese samples of the OC group had increased content of $18 \mathrm{C}$ FA including $\mathrm{C} 18: 1$ cis-9, the sum of C18:1 trans-10 and trans-11, and RA. Moreover, total PUFA and linolenic acid were not affected in milk or in cheese. However, in contrast to the milk FA content, linoleic acid percentages were elevated in cheese obtained from the OC group. Those results agree with Castellani et al. (2017), who reported that proportions of total MUFA, oleic acid, and RA increased and total SFA decreased in cheese, whereas the percentage of total PUFA was not modified by the inclusion of dried olive pomace in the cow diets. Additionally, studies reported decreased SFA and atherogenic index as well as increased total MUFA, C18:1 cis-9, or RA concentrations of cheese fat when 10 and $25 \%$ dried OC
(Vargas-Bello-Pérez et al., 2013) or olive oil (VargasBello-Pérez et al., 2018) were included in the diets of ewes and cows, respectively. Furthermore, these studies observed an increase in total PUFA of cheese lipids in diets enriched with oleic acid. It has been reported that heating, the fermentation culture used, and the ripening time required for the type of cheese produced could all potentially modulate cheese FA composition (Collomb et al., 2006; Domagała et al., 2010; Santillo et al., 2016).

This is the first report studying the effects of the inclusion of OC silage on the lipid metabolism of dairy cows. To our knowledge, no other studies have examined potential effects of any form of OC on mammary or adipose gene expression in lactating cows. The current feeding trial used cows in mid lactation. Therefore, tissue samples were obtained after the period of negative energy balance when extensive lipolysis, upregulation of lipolytic genes, and remarked downregulation of lipogenic genes take place (Sumner-Thomson et al., 2011).

During mid lactation and according to our findings, the transcription level of SREBF1 in adipose tissue was significantly increased in response to the increased level of C18:0 and C18:1 cis-9 in the OC diet. However, no effect on the SREBF1 mRNA abundance of adipose tissue was reported either in nutrigenomic studies conducted in lactating cows after UFA supplementation (Thering et al., 2009; Vahmani et al., 2014) or in a recent in vitro study examining the effect of dose and type of LCFA on adipogenesis of bovine adipocytes (Yanting et al., 2018). In the study of Harvatine et al. (2009), intravenous infusion of trans-10, cis-12 CLA, a well-established inhibitor of de novo milk FA synthesis, upregulated $S R E B F 1$ in adipose tissue of dairy cows. This particular CLA isomer increases the expression of adipogenic SREBF1 and lipid synthesis enzymes (reviewed by Bauman et al., 2011), suggesting energy partitioning toward adipose tissue fat stores (Harvatine et al., 2009). In the present study, however, milk fat content was not affected. Supplementation with OC increased the sum of C18:1 trans-10 and trans-11, the first of which has also been associated with reduced de novo synthesized FA in dairy cows (Dorea and Armentano, 2017). It is likely that increased levels of C18:1 trans-10 or other monoenes arising from oleic acid isomerization may have affected the expression of $S R E B F 1$ in adipose tissue of lactating cows, but further research is needed to clarify the particular role of other bioactive CLA and trans monoenes on lipid metabolism when oleic acid is fed (Dorea and Armentano, 2017).

Regarding the expression of the remaining genes tested in the adipose tissue, no significant differences were observed between treatments. The transcriptional factor 
SREBF1 is a master regulator of lipid synthesis (Osorio et al., 2016); it remains an inactive precursor on the endoplasmic reticulum membrane and is transported to the Golgi for proteolytic cleavage before entering the nucleus, where it activates expression of sterol response element (SRE)-containing genes (ACACA, FASN, and SCD1; Bauman et al., 2011; Osorio et al., 2016). Although SREBF1 was upregulated, we did not observe increased mRNA expression of the genes involved in FA synthesis and desaturation. Similarly, Graugnard et al. (2009) indicated that different levels of starch had no effect on the mRNA expression of $A C A C A$, $F A S N$, and $S C D 1$ in adipose tissue of steers despite elevated mRNA expression of SREBF1, which could possibly be attributed to posttranscriptional regulation of SREBF1. In some studies testing plant oils in bovine (Thering et al., 2009; Vahmani et al., 2014) and caprine (Bernard et al., 2009, 2012) diets, no significant effects on any of the genes expressed in the adipose tissue were reported. The differences of results regarding SREBF1 expression could be related to the levels of OC inclusion or to other factors that need to be further investigated. For instance, differences in plasma insulin concentrations are known to affect adipose lipogenesis (Vernon, 2005). Overall, the results of this study suggest that the adipose tissue lipogenic pathway does not play an important role in the response of mammary lipid secretion to the OC supplement used.

In the present study, the decreased proportion of the de novo $\mathrm{C}<16 \mathrm{FA}$ in the cow milk of the OC group was not accompanied by changes in mammary lipogenic gene expression. Feeding cows ensiled OC was not followed by reduction in milk fat percentage or by changes in the expression of any of the genes involved in mammary lipid synthesis despite the decreased proportion of the de novo FA in milk. Additionally, the secretion of LCFA was increased in the OC group, but this was not accompanied by variations in mammary $L P L$ mRNA abundance or in mRNA abundance of genes involved in the uptake, transport, and trafficking of FA in the cells (CD36, FABP3, VLDLR, SLC2A1). Our results concur with the studies of Bernard et al. (2005, 2009), who observed increased secretion of $18 \mathrm{C} \mathrm{FA}$ in the milk of goats fed plant oils without effect on the $L P L$ mRNA abundance, and with the studies of Bernard et al. (2017) and Fougère and Bernard (2019), who reported no diet effect on the bovine and caprine mammary levels of expression of $L P L, S L C 2 A 1, C D 36$, or FABP3 by lipid supplementation. It is likely that mammary lipid synthesis, FA uptake, and transport are regulated at the posttranscriptional or posttranslational level for these genes or that short-term regulation of mRNA synthesis by nutrient supply may have taken place (Bernard et al., 2017; Fougère and Bernard, 2019).

\section{CONCLUSIONS}

This study examined the inclusion of OC silage $(10 \%$ of DM) in the diets of lactating Holstein-Friesian cows to determine whether it affects milk and corresponding Halloumi FA composition and to examine the expression of key mammary and adipose lipogenic genes. By supplementing cow diets with OC, we observed in both milk and Halloumi cheese increased levels of individual FA that are related to positive effects on human health (i.e., CLA and oleic acid), whereas SFA were decreased. No variation in the mammary and adipose mRNA abundance due to the diets was observed, apart from $S R E B F 1$, which was higher in the adipose tissue of the OC group without affecting the expression of the genes $S R E B F 1$ regulates. The results of the present study are useful for exploiting an abundant, cost-effective by-product of the olive oil industry to improve the FA profile of cow milk and derived Halloumi cheese without negative consequences in milk fat content or milk production.

\section{ACKNOWLEDGMENTS}

This work was supported by the Cyprus University of Technology and the Agricultural Research Institute (ARI) of Cyprus. We thank Andy Mavromoustakos (University of Arkansas, Fayetteville) for statistical advice, the technical staff, and the collaborating vets of the Athalassa experimental ARI farm for the management of the cow herd. We also acknowledge the suggestions and constructive comments from the associate editor and the anonymous reviewers. The authors have not stated any conflicts of interest.

\section{REFERENCES}

Abbeddou, S., B. Rischkowsky, M. E. D. Hilali, M. Haylani, H. D. Hess, and M. Kreuzer. 2015. Supplementing diets of Awassi ewes with olive cake and tomato pomace: On-farm recovery of effects on yield, composition and fatty acid profile of the milk. Trop. Anim. Health Prod. 47:145-152. https://doi.org/10.1007/s11250 -014-0699-x.

Abbeddou, S., B. Rischkowsky, M. E. D. Hilali, H. D. Hess, and M. Kreuzer. 2011a. Influence of feeding Mediterranean food industry by-products and forages to Awassi sheep on physicochemical properties of milk, yoghurt and cheese. J. Dairy Res. 78:426-435. https: //doi.org/10.1017/S0022029911000665.

Abbeddou, S., B. Rischkowsky, E. K. Richter, H. D. Hess, and M Kreuzer. 2011b. Modification of milk fatty acid composition by feeding forages and agro-industrial byproducts from dry areas to Awassi sheep. J. Dairy Sci. 94:4657-4668. https://doi.org/10 .3168/jds.2011-4154.

AOAC International. 2005. Official Methods of Analysis. 18th ed. AOAC Int., Gaithersburg, MD.

Arco-Pérez, A., E. Ramos-Morales, D. R. Yáñez-Ruiz, L. Abecia, and A. I. Martín-García. 2017. Nutritive evaluation and milk quality of including of tomato or olive by-products silages with sunflower oil in the diet of dairy goats. Anim. Feed Sci. Technol. 232:57-70. https://doi.org/10.1016/j.anifeedsci.2017.08.008. 
Bauman, D. E., K. J. Harvatine, and A. L. Lock. 2011. Nutrigenomics, rumen-derived bioactive fatty acids, and the regulation of milk fat synthesis. Annu. Rev. Nutr. 31:299-319. https://doi.org/10.1146/ annurev.nutr.012809.104648.

Bauman, D. E., I. H. Mather, R. J. Wall, and A. L. Lock. 2006. Major advances associated with the biosynthesis of milk. J. Dairy Sci. 89:1235-1243. https://doi.org/10.3168/jds.S0022-0302(06)72192 -0 .

Bernard, L., M. Bonnet, C. Leroux, K. J. Shingfield, and Y. Chilliard. 2009. Effect of sunflower-seed oil and linseed oil on tissue lipid metabolism, gene expression, and milk fatty acid secretion in Alpine goats fed maize silage-based diets. J. Dairy Sci. 92:6083-6094. https://doi.org/10.3168/jds.2009-2048.

Bernard, L., C. Leroux, M. Bonnet, J. Rouel, P. Martin, and Y. Chilliard. 2005. Expression and nutritional regulation of lipogenic genes in mammary gland and adipose tissues of lactating goats. J. Dairy Res. 72:250-255. https://doi.org/10.1017/s0022029905000786.

Bernard, L., C. Leroux, J. Rouel, M. Bonnet, and Y. Chilliard. 2012. Effect of the level and type of starchy concentrate on tissue lipid metabolism, gene expression and milk fatty acid secretion in Alpine goats receiving a diet rich in sunflower-seed oil. Br. J. Nutr. 107:1147-1159. https://doi.org/10.1017/S0007114511004181.

Bernard, L., P. G. Toral, and Y. Chilliard. 2017. Comparison of mammary lipid metabolism in dairy cows and goats fed diets supplemented with starch, plant oil, or fish oil. J. Dairy Sci. 100:93389351. https://doi.org/10.3168/jds.2017-12789.

Bionaz, M., and J. J. Loor. 2007. Identification of reference genes for quantitative real-time PCR in the bovine mammary gland during the lactation cycle. Physiol. Genomics 29:312-319. https://doi .org/10.1152/physiolgenomics.00223.2006.

Bionaz, M., and J. J. Loor. 2008. Gene networks driving bovine milk fat synthesis during the lactation cycle. BMC Genomics 9:366. https://doi.org/10.1186/1471-2164-9-366.

Buccioni, A., M. Decandia, S. Minieri, G. Molle, and A. Cabiddu. 2012. Lipid metabolism in the rumen: New insights on lipolysis and biohydrogenation with an emphasis on the role of endogenous plant factors. Anim. Feed Sci. Technol. 174:1-25. https://doi.org/ 10.1016/j.anifeedsci.2012.02.009.

Butler, G., S. Stergiadis, C. Seal, M. Eyre, and C. Leifert. 2011. Fat composition of organic and conventional retail milk in northeast England. J. Dairy Sci. 94:24-36. https://doi.org/10.3168/jds.2010 -3331 .

Castellani, F., A. Vitali, N. Bernardi, E. Marone, F. Palazzo, L. Grotta, and G. Martino. 2017. Dietary supplementation with dried olive pomace in dairy cows modifies the composition of fatty acids and the aromatic profile in milk and related cheese. J. Dairy Sci. 100:8658-8669. https://doi.org/10.3168/jds.2017-12899.

Chilliard, Y., A. Ferlay, R. Mansbridge, and M. Doreau. 2000. Ruminant milk fat plasticity: Nutritional control of saturated, polyunsaturated, trans and conjugated fatty acids. Ann. Zootech. 49:181205. https://doi.org/10.1051/animres:2000117.

Chilliard, Y., A. Ferlay, J. Rouel, and G. Lamberet. 2003. A review of nutritional and physiological factors affecting goat milk lipid synthesis and lipolysis. J. Dairy Sci. 86:1751-1770. https://doi.org/10 .3168/jds.S0022-0302(03)73761-8.

Chilliard, Y., F. Glasser, A. Ferlay, L. Bernard, J. Rouel, and M. Doreau. 2007. Diet, rumen biohydrogenation and nutritional quality of cow and goat milk fat. Eur. J. Lipid Sci. Technol. 109:828855. https://doi.org/10.1002/ejlt.200700080.

Chiofalo, B., L. Liotta, V. Chiofalo, and A. Zumbo. 2002. La sansa d'oliva nell'alimentazione degli ovini: Effetto sulla composizione acidica del latte (Olive cake for ewe feeding: Effect on the milk acidic composition). Pages 136-137 in 15th National Congress of Società Italiana di Patologia e Allevamento degli Ovini e dei Caprini (SIPAOC), Cagliari, Italy. SIPAOC, Cagliari, Italy.

Chiofalo, B., L. Liotta, A. Zumbo, and V. Chiofalo. 2004. Administration of olive cake for ewe feeding: Effect on milk yield and composition. Small Rumin. Res. 55:169-176. https://doi.org/10.1016/j .smallrumres.2003.12.011.

Collomb, M., A. Schmid, R. Sieber, D. Wechsler, and E. L. Ryhänen. 2006. Conjugated linoleic acids in milk fat: Variation and physi- ological effects. Int. Dairy J. 16:1347-1361. https://doi.org/10 .1016/j.idairyj.2006.06.021.

Domagała, J., M. Sady, T. Grega, H. Pustkowiak, and A. Florkiewicz. 2010. The influence of cheese type and fat extraction method on the content of conjugated linoleic acid. J. Food Compos. Anal. 23:238-243. https://doi.org/10.1016/j.jfca.2009.11.002.

Dorea, J. R. R., and L. E. Armentano. 2017. Effects of common dietary fatty acids on milk yield and concentrations of fat and fatty acids in dairy cattle. Pages 2224-2236 in Animal Production Science. CSIRO, Canberra, Australia.

European Union. 2010. Directive 2010/63/EU of the European Parliament and of the Council of 22 September 2010 on the protection of animals used for scientific purposes. Off. J. L276:33-79.

Feng, S., A. L. Lock, and P. C. Garnsworthy. 2004. Technical note: A rapid lipid separation method for determining fatty acid composition of milk. J. Dairy Sci. 87:3785-3788. https://doi.org/10.3168/ jds.S0022-0302(04)73517-1.

Ferlay, A., L. Bernard, A. Meynadier, and C. Malpuech-Brugère. 2017. Production of trans and conjugated fatty acids in dairy ruminants and their putative effects on human health: A review. Biochimie 141:107-120. https://doi.org/10.1016/j.biochi.2017.08.006.

Fougère, H., and L. Bernard. 2019. Effect of diets supplemented with starch and corn oil, marine algae, or hydrogenated palm oil on mammary lipogenic gene expression in cows and goats: A comparative study. J. Dairy Sci. 102:768-779. https://doi.org/10.3168/ jds.2018-15288.

Garnsworthy, P. C., S. Feng, A. L. Lock, and M. D. Royal. 2010. Short communication: Heritability of milk fatty acid composition and stearoyl-CoA desaturase indices in dairy cows. J. Dairy Sci 93:1743-1748. https://doi.org/10.3168/jds.2009-2695.

Gaynor, P. J., R. A. Erdman, B. B. Teter, J. Sampugna, A. V. Capuco, D. R. Waldo, and M. Hamosh. 1994. Milk fat yield and composition during abomasal infusion of cis or trans octadecenoates in Holstein cows. J. Dairy Sci. 77:157-165. https://doi.org/10.3168/ jds.S0022-0302(94)76938-1.

Graugnard, D. E., P. Piantoni, M. Bionaz, L. L. Berger, D. B. Faulkner, and J. J. Loor. 2009. Adipogenic and energy metabolism gene networks in Longissimus lumborum during rapid post-weaning growth in Angus and Angus $\times$ Simmental cattle fed high-starch or low-starch diets. BMC Genomics 10:142. https://doi.org/10.1186/ 1471-2164-10-142.

Griinari, J. M., D. A. Dwyer, M. A. Mcguire, D. E. Bauman, D. L. Palmquist, and K. V. V. Nurmela. 1998. Trans-octadecenoic acids and milk fat depression in lactating dairy cows. J. Dairy Sci. 81:1251-1261. https://doi.org/10.3168/jds.S0022-0302(98)75686 $-3$.

Hadjipanayiotou, M. 1999. Feeding ensiled crude olive cake to lactating Chios ewes, Damascus goats and Friesian cows. Livest. Prod. Sci. 59:61-66. https://doi.org/10.1016/S0301-6226(99)00005-6.

Harvatine, K. J., J. W. Perfield II, and D. E. Bauman. 2009. Expression of enzymes and key regulators of lipid synthesis is upregulated in adipose tissue during CLA-induced milk fat depression in dairy cows. J. Nutr. 139:849-854. https://doi.org/10.3945/jn.108 .099994.

He, M., K. L. Perfield, H. B. Green, and L. E. Armentano. 2012. Effect of dietary fat blend enriched in oleic or linoleic acid and monensin supplementation on dairy cattle performance, milk fatty acid profiles, and milk fat depression. J. Dairy Sci. 95:1447-1461. https:// doi.org/10.3168/jds.2011-4635.

ISO (International Organization for Standardization). 2002. Animal and vegetable fats and oils - Preparation of methyl esters of fatty acids. ISO method 5509:2000. ISO, Geneva, Switzerland.

Kaps, M., and W. R. Lamberson. 2009. Biostatistics for Animal Science. 2nd ed. CABI, Wallingford, UK.

Kramer, J. K. G., M. Hernandez, C. Cruz-Hernandez, J. Kraft, and M. E. R. Dugan. 2008. Combining results of two GC separations partly achieves determination of all cis and trans 16:1, 18:1, 18:2 and 18:3 except CLA isomers of milk fat as demonstrated using ag-ion SPE fractionation. Lipids 43:259-273. https://doi.org/10 $.1007 / \mathrm{s} 11745-007-3143-4$. 
Lock, A. L., and D. E. Bauman. 2004. Modifying milk fat composition of dairy cows to enhance fatty acids beneficial to human health. Lipids 39:1197-1206. https://doi.org/10.1007/s11745-004-1348-6.

Meo Zilio, D., S. Bartocci, S. Di Giovanni, M. Servili, A. Chiariotti, and S. Terramoccia. 2014. Evaluation of dried stoned olive pomace as supplementation for lactating Holstein cattle: Effect on milk production and quality. Anim. Prod. Sci. 55:185-188. https://doi .org/10.1071/AN14254.

Molina-Alcaide, E., E. Y. Morales-García, A. I. Martín-García, H. Ben Salem, A. Nefzaoui, and M. R. Sanz-Sampelayo. 2010. Effects of partial replacement of concentrate with feed blocks on nutrient utilization, microbial $\mathrm{N}$ flow, and milk yield and composition in goats. J. Dairy Sci. 93:2076-2087. https://doi.org/10.3168/jds $.2009-2628$

Molina-Alcaide, E., and D. R. Yáñez-Ruiz. 2008. Potential use of olive by-products in ruminant feeding: A review. Anim. Feed Sci. Technol. 147:247-264. https://doi.org/10.1016/j.anifeedsci.2007 .09.021.

NRC. 2001. Nutrient Requirements of Dairy Cattle. 7th rev. ed. National Academy Press, Washington, DC.

Osorio, J. S., J. Lohakare, and M. Bionaz. 2016. Biosynthesis of milk fat, protein, and lactose: Roles of transcriptional and posttranscriptional regulation. Physiol. Genomics 48:231-256. https://doi .org/10.1152/physiolgenomics.00016.2015.

Owaimer, A. N., M. S. Kraidees, M. Al-Saiady, S. Zahran, and M. A. Abouheif. 2004. Effect of feeding olive cake in complete diet on performance and nutrient utilization of lambs. Asian-Australas. J. Anim. Sci. 17:491-496. https://doi.org/10.5713/ajas.2004.491.

Palmquist, D. L. 2009. Omega-3 fatty acids in metabolism, health, and nutrition and for modified animal product foods. Prof. Anim. Sci. 25:207-249. https://doi.org/10.15232/S1080-7446(15)30713-0.

Papademas, P., and R. K. Robinson. 1998. Halloumi cheese: The product and its characteristics. Int. J. Dairy Technol. 51:98-103. https: //doi.org/10.1111/j.1471-0307.1998.tb02646.x.

Parodi, P. 2004. Milk fat in human nutrition. Aust. J. Dairy Technol. $59: 3-8$.

Republic of Cyprus. 1994. The Law for the Protection, Health and Welfare of Animals of 1994.

Santillo, A., M. Caroprese, R. Marino, F. d'Angelo, A. Sevi, and M. Albenzio. 2016. Fatty acid profile of milk and Cacioricotta cheese from Italian Simmental cows as affected by dietary flaxseed supplementation. J. Dairy Sci. 99:2545-2551. https://doi.org/10 $.3168 /$ jds.2015-10419.

Shingfield, K. J., L. Bernard, C. Leroux, and Y. Chilliard. 2010. Role of trans fatty acids in the nutritional regulation of mammary lipogenesis in ruminants. Animal 4:1140-1166. https://doi.org/10 $.1017 /$ S1751731110000510.

Shingfield, K. J., A. Sæbø, P. C. Sæbø, V. Toivonen, and J. M. Griinari. 2009. Effect of abomasal infusions of a mixture of octadecenoic acids on milk fat synthesis in lactating cows. J. Dairy Sci. 92:4317-4329. https://doi.org/10.3168/jds.2008-2002.

Sumner-Thomson, J. M., J. L. Vierck, and J. P. McNamara. 2011. Differential expression of genes in adipose tissue of first-lactation dairy cattle. J. Dairy Sci. 94:361-369. https://doi.org/10.3168/jds .2010-3447.

Symeou, S., C. G. Tsiafoulis, I. P. Gerothanassis, D. Miltiadou, and O. Tzamaloukas. 2019. Nuclear magnetic resonance screening of changes in fatty acid and cholesterol content of ovine milk induced by ensiled olive cake inclusion in Chios sheep diets. Small Rumin. Res. 177:111-116. https://doi.org/10.1016/j.smallrumres.2019.06 .017 .
Thering, B. J., D. E. Graugnard, P. Piantoni, and J. J. Loor. 2009 Adipose tissue lipogenic gene networks due to lipid feeding and milk fat depression in lactating cows. J. Dairy Sci. 92:4290-4300. https://doi.org/10.3168/jds.2008-2000.

Toral, P. G., G. Hervás, A. Belenguer, D. Carreño, and P. Frutos. 2017. mRNA abundance of genes involved in mammary lipogenesis during fish oil- or trans-10,cis-12 CLA-induced milk fat depression in dairy ewes. J. Dairy Sci. 100:3182-3192. https://doi.org/10 .3168/jds.2016-11814.

Tsiafoulis, C. G., T. Skarlas, O. Tzamaloukas, D. Miltiadou, and I. P. Gerothanassis. 2014. Direct nuclear magnetic resonance identification and quantification of geometric isomers of conjugated linoleic acid in milk lipid fraction without derivatization steps: Overcoming sensitivity and resolution barriers. Anal. Chim. Acta 821:62-71. https://doi.org/10.1016/j.aca.2014.03.010.

Ulbricht, T. L., and D. Southgate. 1991. Coronary heart disease: Seven dietary factors. Lancet 338:985-992. https://doi.org/10.1016/0140 -6736(91)91846-M.

Vahmani, P., K. E. Glover, and A. H. Fredeen. 2014. Effects of pasture versus confinement and marine oil supplementation on the expression of genes involved in lipid metabolism in mammary, liver, and adipose tissues of lactating dairy cows. J. Dairy Sci. 97:4174-4183. https://doi.org/10.3168/jds.2013-7290.

Van Soest, P. J., J. B. Robertson, and B. A. Lewis. 1991. Methods for dietary fiber, neutral detergent fiber, and nonstarch polysaccharides in relation to animal nutrition. J. Dairy Sci. 74:3583-3597. https://doi.org/10.3168/jds.S0022-0302(91)78551-2.

Vargas-Bello-Pérez, E., C. Geldsetzer-Mendoza, M. S. Morales, P. Toro-Mujica, M. A. Fellenberg, R. A. Ibáñez, P. Gómez-Cortés, and P. C. Garnsworthy. 2018. Effect of olive oil in dairy cow diets on the fatty acid profile and sensory characteristics of cheese. Int. Dairy J. 85:8-15. https://doi.org/10.1016/j.idairyj.2018.04.006.

Vargas-Bello-Pérez, E., R. R. Vera, C. Aguilar, R. Lira, I. Peña, and J. Fernández. 2013. Feeding olive cake to ewes improves fatty acid profile of milk and cheese. Anim. Feed Sci. Technol. 184:94-99. https://doi.org/10.1016/j.anifeedsci.2013.05.016.

Vernon, R. G. 2005. Lipid metabolism during lactation: A review of adipose tissue-liver interactions and the development of fatty liver. J. Dairy Res. 72:460-469. https://doi.org/10.1017/ S0022029905001299.

Weld, K. A., and L. E. Armentano. 2018. Feeding high oleic acid soybeans in place of conventional soybeans increases milk fat concentration. J. Dairy Sci. 101:9768-9776. https://doi.org/10.3168/ jds.2018-14498.

Yanting, C., Q. Y. Yang, G. L. Ma, M. Du, J. H. Harrison, and E. Block. 2018. Dose- and type-dependent effects of long-chain fatty acids on adipogenesis and lipogenesis of bovine adipocytes. J. Dairy Sci. 101:1601-1615. https://doi.org/10.3168/jds.2017-13312.

\section{ORCIDS}

M. C. Neofytou $\odot$ https://orcid.org/0000-0002-1234-2337

D. Miltiadou ๑ https://orcid.org/0000-0002-5940-3520

E. Sfakianaki (ㄴ https://orcid.org/0000-0001-7636-0182

C. Constantinou (๑) https://orcid.org/0000-0001-7512-2852

S. Symeou () https://orcid.org/0000-0002-9844-3517

D. Sparaggis (1) https://orcid.org/0000-0002-1461-4033

A. L. Hager-Theodorides @ https://orcid.org/0000-0002-8480-3200

O. Tzamaloukas () https://orcid.org/0000-0001-7675-6718 